\title{
RESEARCH
}

Open Access

\section{Brain drain of agriculture and veterinary graduates to abroad: evidence from Nepal}

\author{
Rishi Ram Kattel ${ }^{1}$ and Mahesh Sapkota ${ }^{2^{*}}$ (1)
}

\begin{abstract}
Background: Though the migration of skilled manpower is common all over the world, it has created serious problem and huge loss to least developed countries like Nepal. Most of the skilled manpowers are attracted toward developed countries through better incentives, scholarships and better services and facilities. Although remittance has significant and high contribution to national gross domestic product but in long term, it reduces human welfare and economic growth of the nation. Nowadays, migration of agriculture and veterinary graduates is increasing day by day resulting in scarcity of skilled manpower in this sector. This paper aimed to assess the magnitude and determinants of the brain drain of Nepali agriculture and veterinary graduates to abroad, showing that brain drain (or high-skill migration) is becoming dominant pattern of international migration and a major aspect of globalization.
\end{abstract}

Methods: Web-based structural survey questionnaire was used to assess push and pull factors to migrate abroad and factors determination among already brain drained respondents and students those studying agriculture and veterinary in Nepal. The total of 450 samples were obtained from online survey as well as few face-to face interviews in July 2015. Descriptive analysis and Logit model were used to derive necessary inferences using Stata software.

Results: The study revealed that about $52 \%$ of students intend to go abroad, either to pursue higher study or for better job opportunities and better livelihood. Poor higher education system in Nepal (42.7\%), socioeconomic condition (29.8\%) and desire to go abroad (25\%) were major push factors toward brain drain, whereas high income and better living standard (29.7\%), better job and working environment (25.6\%), family future security (17.4\%), personal freedom (9.9\%) and political stability in abroad (10.7\%) were found major pulling factors of skilled manpower to abroad from Nepal. Logit model revealed that the age of respondent and household member migration to abroad were positive and significant determining factors for brain drain, whereas total household income has negative impact on brain drain controlling other socioeconomic variables.

Conclusion: This study identified that majority of the students studying agriculture and veterinary sciences in Nepal are willing to go abroad either for better higher education or for better living standard and job opportunities. This suggests that brain drain is individual feature in least developed country like Nepal and government should formulate better policy to control brain drain considering all consequences that can hamper economic growth of the country.

Keywords: Agriculture and veterinary graduates, Brain drain, Logit, Nepal

\footnotetext{
*Correspondence: sapkotamahes@gmail.com

${ }^{2}$ Department of Agriculture, Ministry of Agriculture and Livestock

Development, Hariharbhawan, Lalitpur, Nepal

Full list of author information is available at the end of the article
} 


\section{Introduction}

The migration of skilled manpower from least developed countries to developed countries is a global phenomenon and this has helped developed countries to be more stable and prosperous, whereas least developed countries are losing their pillars for the development of the nation. Most of the people migrate from poor and least developed countries to rich and developed countries those are advanced in industrialization and mechanization. Educated skilled graduates are attracted toward developed countries in the form of incentives, scholarships, better living standard and political stability, better job opportunities, etc. It is generally argued that this outflow is compensated through remittances and brain circulation. But this has created a lack of educated and skilled graduates in the respective field which has created a huge gap in the economic development of the country. Brain drain refers to the migration of skilled and educated labor, rooted precariously in the least developed and developing countries since many years. The causes of brain drain can be well justified by pull and push factors like unemployment, liberty, topographical challenge, salary and better opportunities [1]. The development of any country is based on the development of the industrial sector. The shortage of a qualified skilled worker in the country slows the pace of development. The various pull factors of developed countries are attracting a number of skilled manpower from developing countries. The imbalance in population and economic growth has resulted in migration. This has created good source of skilled manpower for developed countries and situation of underemployment and scarce of the educated population (skilled manpower) in LDCs and developing countries.

Nepal is also exporting substantial human capital either in the form of labor or in the form of skilled manpower. About more than thousand youths migrate abroad specially gulf countries and then European and American countries for various purposes. The remittance is becoming the major source of the national economy contributing around 28\% to national GDP [2]. Better education opportunities and better facilities at abroad are major pull factors for the migration from Nepal. Migration have positive effects such as inflow of huge money and transfer of technology. But, larger migration of skilled and educated people has created scarcity of skilled human resources in the country. Economic growth rate and existing situation of the country is crucial and has high influence on the migration rate of graduates and skilled manpower. High emigration has helped in reducing the poverty due to high remittance flow inside the country. The increase in remittances has reduced the poverty from 49 to $25 \%$ in Nepal [3]. Although remittance, skills and entrepreneurship have brought economic benefits, in long term, it reduces the human welfare and economic growth in the least developed countries. A similar threat is felt in Nepal. The problem of brain drain in agriculture and veterinary graduates is prominent. Many of the graduates migrate abroad for further study but they do not return to their home country which has created severe brain drain problem in Nepal. The status of skilled brain drain has brought negative growth effects due to loss of productive resources from the country. Many graduates go abroad and learn new, high and improved technologies who can contribute directly for the economic development of their country. Some emigrants are using the knowledge and skills gained in abroad to uplift the local economic situation and for better living standard in their own country.

Nepal is at transitional phase due to recent change in government structure to federal democratic republican country. The development of the country is handicapped by high political instability (10 prime ministers in a time period of one decade, 2008-2018) and lack of good governance resulting in higher outmigration for study and employment opportunities. This has also hindered innovation, and country is forced toward remittance-based development model. Nepal is at an early stage of brain drain, so government should focus and bring attractive strategy to reduce emigration and should create a better environment to attract the migrant skilled manpower. According to the Department of Foreign Employment, about 1200 Nepali per day go to abroad in search of better opportunities. The rate of migration of students to the United States of America (USA) and Australia is increasing day by day at a rapid rate. According to the Institute for International Education in New York, there was increase in Nepali students in the USA by $27.9 \%$ in the year 2006-2007 and total students has reached to 7754 . Nepal is at 13th position as compared to the 23rd position in 2004 in case of a number of students studying in the USA. About NRs. 54 billion is spent during 19972000 for studying in abroad. Similarly, the figure was double in the year 1990-2005 spending more than NRs. 30 billion annually to study in countries other than India (http://nepalitimes.com/news.php?id=15211\#.V4IVP fl97IU).

In Nepal, Institute of Agriculture and Animal Science (IAAS) under Tribhuvan University (TU) was established in 1972 which provides higher education up to Ph.D. level in agriculture and veterinary field. To address the current demand and to ensure quality education, the Agriculture and Forestry University (AFU) was established in 2010. Similarly, there is an increase in private colleges nowadays to provide agriculture education to students. There is a large number of graduate students per year in the field of agriculture and veterinary but the country is 
facing lack of technical manpower in agriculture field. It is only because of high emigration to abroad for higher study and in search of better opportunities and not returning to their home country [4]. About 250 agriculture graduates, 70 veterinarians and 80 forestry graduates are produced annually but more than $30 \%$ of them go to abroad in search of better opportunities [5]. In Nepal, the ratio of technician to farmers is $1: 1500$, whereas the ratio in developed countries is 1:400 [6]. Nepal government is investing huge amount of money in agriculture and veterinary sector to produce skilled manpower in this sector. Most of them study under government scholarship schemes and very few from the private sector. The economic cost of migrated students is in billion, and a large share is from agricultural graduates. There is no such study in Nepal to identify the causes of brain drain. The government has not succeeded to bring the appropriate policy to minimize the problem of brain drain. This study helps the government sector as well as other stakeholders for future research and policy dialogue to stop the increasing trend of brain drain to abroad.

The study was conducted based on the following objectives:

1. to investigate the perceived influencing factors toward brain drain among Nepali agriculture and veterinary graduates

2. to identify the determinants of brain drain of agriculture and veterinary graduates

3. to suggest remedial measures to minimize brain drain

\section{Literature review}

There is high emigration towards the country where there is more and better career opportunities, high remuneration and high civil liberties [7]. In Zimbabwe, number of skilled manpower migrating to abroad is increasing, and mainly the health and teaching professions were most affected due to brain drain [8]. The major causes behind brain drain were due to work-related factors (low salary in the country) followed by to attend higher education, whereas majority of the respondents (62.5\%) stated that they were willing to return to their country and $25 \%$ were not sure that they would return or not. There were more young and old-aged groups who showed interest to return to their country. Tansel and Gungor [9] concluded that $25 \%$ of the respondents preferred abroad study for prestige and facilities associated at abroad. In Turkey, main reason for brain drain was unavailability of sophisticated laboratory and equipment/tools. Migrants from Turkey were not willing to return to their country because of economic crisis, lack of employment and political instability.
Iravani [10] conducted research in Iran using census data from United Nation Institute for training and research. T-Psycho social problem, economic and political instability were the major factors affecting the brain drain. The educated people being at the state of unemployment was found as a major alarming problem in many countries like Pakistan, Iran, Nigeria, South Korea, Philippines, Columbia, China and India. Iravani concluded that the major reasons of brain drain were less employment generation, inappropriate job according to job qualification, over production and lack of experience to compete in those jobs which require high efficiency, training and academic excellence. It identified that the problem of brain drain can be reduced by providing job to their expertise field so that they can prove their capabilities.

Simon Commander [11] analyzed analytical and empirical literature and concluded that the brain drain of skilled manpower from the country is most detrimental for the development of the country.

Gouda et al. [12] in a survey of Irish medical students going abroad after graduation or before internship revealed better career scope (85\%), unfavorable working situation $(83 \%)$, better lifestyle $(80 \%)$, handsome salary $(65 \%)$ and training standard (60\%) were the major factors influencing brain drain in country. Oyelere [13] stated that the brain drain from health sector is an emerging issue. The study revealed that the cost involved to educate individual from primary level up to medical doctor was around US\$ 66,000 and loss was US\$ 517,931 worth from investment who migrates. The total cost of educating a nurse in Kenya was about US\$ 43,000, and if migrates then loss incurred was about US\$ 338,868 worth of returns from investment. This data of Kenya showed a huge loss to any country when there is a migration of skilled manpower and has attracted the attention of government to reduce this problem.

Johnson [14] stated that low economic status and poor countries face difficulty to compete globally and difficult to retain skilled manpower. Riano [15] studied about the labor market situation of women and most of the respondents responded that they were insecure in the labor market. The majority of skilled migrant women faced problems of loss of their capabilities (about 50\% respondents were not having appropriate job as per their qualifications), confidence and lack of freedom to work independently. Therefore, the majority of the women felt no improvement due to migration, and they found the loss in their social status. In case of migrant skilled women, they were not awarded with high professional status, especially to those from countries other than EU. Skilled migrant women had to do any sort of job available as it was very difficult to find the job according to their qualifications. 


\section{Research methodology}

The respondents in this survey were confined to the Nepali agriculture and veterinary students and graduates from Nepal and abroad. The collection of data was done by internet survey using survey face online survey questionnaire (www.surveyface.com) and few by direct face-to-face interview. The questionnaire was prepared online using survey face web page. The semi-structured questionnaire consisted of section of demographic information, level of education received, source of income, further career-related intentions and some variables related to push and pull factors.

The web address containing questionnaire was disseminated to agriculture and veterinary graduates staying at Nepal and at abroad via email, Facebook messenger, post on the wall of agriculture-related common groups in Facebook. In order to avoid duplication of filling form, respondents were requested not to fill twice at the time of sending questionnaire link. Email addresses of potential respondents working at I/NGOs were collected via phone calls and Facebook messenger. The email addresses, studying and staying at abroad were collected via individual contact and alumni pages on Facebook. Few direct faceface interview was done with the students of Institute of Agriculture and Animal Science (IAAS) and Agriculture and Forestry University (AFU) at Rampur, Chitwan. During face-to-face interview, to avoid duplication, the confirmation was made that they had not participated in the survey by any means. This collected sample through faceto-face interview was entered in Microsoft Excel.

The data collection was started from mid-July 2015 and ended on August 2015. It took about one and half months to collect responses. Altogether there were 450 samples via online and purposive random sampling. The responses with incomplete information were sort out and removed. Therefore, the number of samples varies in different variables in the result section. During data collection, it was difficult to collect responses from the respondents who were abroad. It might be due to the word 'brain drain' used for them. They found the word 'brain drain' abusive for them. Microsoft Excel, Statistical Packages for Social Science (SPSS) and Stata software were used to analyze the data. Descriptive analysis and Logit model to assess factors influencing migration of agriculture and veterinary graduates to abroad were analyzed.

The decision of migration to abroad for higher study and better job opportunities was estimated using Logit model to derive the determinants of brain drain $\left(Y_{i}=1\right)$. Logit model was used in three cases, already migrated to abroad $\left(Y_{1}=1\right)$, plan to go abroad $\left(Y_{2}=1\right)$ and already migrated to abroad plus plan to go abroad $\left(Y_{3}=1\right)$. The dependent variable in Logit model has a binary response, $Y_{i}=1$ if migration=yes, otherwise 0 . Socioeconomic, demographic and institutional variables were used as explanatory variables in the model to measure the probability of a decision to migrate abroad.

The Logit model was based on the following econometric expression:

$$
\begin{aligned}
Y= & \beta_{0}+\beta_{1} X_{1}+\beta_{2} X_{2}+\beta_{3} X_{3}+\beta_{4} X_{4}+\beta_{5} X_{5} \\
& +\beta_{6} X_{6}+\beta_{7} X_{7}+\beta_{8} X_{8}+e_{i}
\end{aligned}
$$

where $Y$ is the dependent variable having a binary response. $Y=1$ if migrated to abroad, otherwise 0 . $\beta_{0}=$ Constant term, $X_{1}=$ Age of respondent, $X_{2}=$ Gender of respondent, $X_{3}=$ Household size, $X_{4}=$ Marital status, $X_{5}=$ Occupation of household head, $X_{6}=$ Education of mother, $X_{7}=$ Annual household income, $X_{8}=$ Migration status from household, $e=$ Error term, $\beta_{1} \ldots \beta_{8}$ are the regression coefficients to be estimated.

\section{Results and discussion}

\section{Socio-demographic characteristics of the respondents}

The total sample size was 450 and there were some missing data in some of the variables. Therefore, the sample size varies to the variables described here in this section. With respect to gender, there was missing data on about 55 samples. Thus, out of 395 respondents in the variable gender, majority of the respondents were male $(63 \%)$ followed by female (37\%). This reflects the fact that population of male students is greater than female in agriculture and veterinary sciences in the present context. Similarly, most of the respondents were unmarried, i.e., about $70.7 \%$ as majority of the respondents were below 30 years of age. There is good linkage and connection of students studying bachelor degree at Nepal with students studying at abroad which make ease to go abroad and go at early age. The age-group of respondents was classified under four age-groups as less than $20,21-30,31-40$ and over 40 years. The majority of respondents were between 21 and 30 years of age (75.3\%) followed by $31-40$ years of age (13.9\%). Up to bachelor degree, it is 17 years of schooling in Nepal, so most of them fall under the age-group of 21-30 years. The majority of respondents (78.5\%) did not have any of the family members at abroad. This might be due to poor access and socioeconomic condition of the respondent's household. About 21.5\% of the respondents households have at least one family member abroad either for work or for education in gulf countries, European countries, USA and Australia (Table 1). 
Table 1 Socio-demographic characteristics of the respondents. Source: Online and field survey, 2015

\begin{tabular}{lcc}
\hline Variables & Frequency & Percent \\
\hline Gender of respondent: $(n=395)$ & 249 & 63 \\
Male & 146 & 37 \\
Female & & \\
Marital status of respondent: $(n=393)$ & 278 & 70.7 \\
Unmarried & 115 & 29.3 \\
Married & & \\
Age category of respondent: $(n=396)$ & 39 & 9.8 \\
Less than 20 years & 295 & 75.3 \\
$21-30$ years & 55 & 13.9 \\
$31-40$ years & 7 & 1 \\
Above 40 years & 84 & 21.5 \\
Migration status of family member to abroad: $(n=390)$ & 78.5 \\
Yes & 306 & \\
No & & \\
\hline
\end{tabular}

Plan after graduation and knowledge about the consequences and control of brain drain Among the students currently pursuing bachelor degree education in agriculture institutions, $51.9 \%$ of students intend to go abroad for further study and grab better job opportunities and better livelihood. Similarly, $48.1 \%$ students intend to stay at Nepal with an aim to pursue their careers in the different service sectors (GOs, I/NGOs, etc.) or run own business. This revealed that the majority of the student studying either agriculture or veterinary would like to go abroad.

Out of the total 341 respondents, almost all (95.6\%) were aware of the consequences of brain drain to the society and country and $4.4 \%$ were unaware about the consequences of brain drain. This might be due to access of most of respondents to the media via different means like newspapers, web, television and various sources. This might be attributed to the education level of respondent (Table 2).

The results showed that most of the respondents $(82.8 \%)$ agreed or believed that brain drain could be controlled through an improvement in the education system in the country, availability of better job opportunities and better livelihood options and improved socio-political situation in the country as shown in Table 2. About $17 \%$ of the respondents were not optimistic about that brain drain could be controlled owing to the globalization, better opportunities and stable situations at abroad.
Table 2 Plan after graduation, knowledge about the consequences and control of brain drain Source: Online and field survey, 2015

\begin{tabular}{lcc}
\hline Variables & Frequency & Percent \\
\hline $\begin{array}{l}\text { Plan after graduation of agriculture and veterinary studying students: } \\
\quad(n=266)\end{array}$ & 128 & 48.1 \\
Stay in Nepal & 138 & 51.9 \\
Pursue abroad study & & \\
Know consequences of brain drain: $(n=341)$ & 326 & 95.6 \\
Yes & 15 & 4.4 \\
No & & \\
Could brain drain be controlled: $(n=379)$ & 314 & 82.8 \\
Yes & 65 & 17.2 \\
No & & \\
\hline
\end{tabular}

Push and pull factors for brain drain of agriculture and veterinary graduates

To determine the push factor, the factors were classified into four categories such as poor higher education system of the country, socioeconomic situation, desire of the individual to go abroad and others. The responses were collected in these factors, and it was found that about $43 \%$ of the respondents responded that the major push factor for the brain drain was due to the poor higher education system of the country. Similarly, about 30,25 and $2 \%$ of the respondents responded on the socioeconomic situation, desire of the individual to go abroad and other factors, respectively (Fig. 1). The study revealed that the poor higher education system of the country was the major factor for brain drain of agriculture and veterinary students from the country.

To determine the pull factors, the factors were classified into five categories such as high income and living standard, better job and working environment, family future security, personal freedom and political stability. In this study, about $30 \%$ of the respondents responded high income and better living standard as the major pull factor to attract agriculture and veterinary students to abroad (Fig. 2). Similarly, about $26 \%$ of the respondents responded better job and working environment whereas $17 \%$ responded family future security as major pull factors. The other pull factors such as personal freedom, political stability and other factors accounted for about 10, 11 and $7 \%$, respectively. The study revealed that higher income and better living standard at abroad were the major pulling factors for brain drain among Nepali agriculture and veterinary students. 


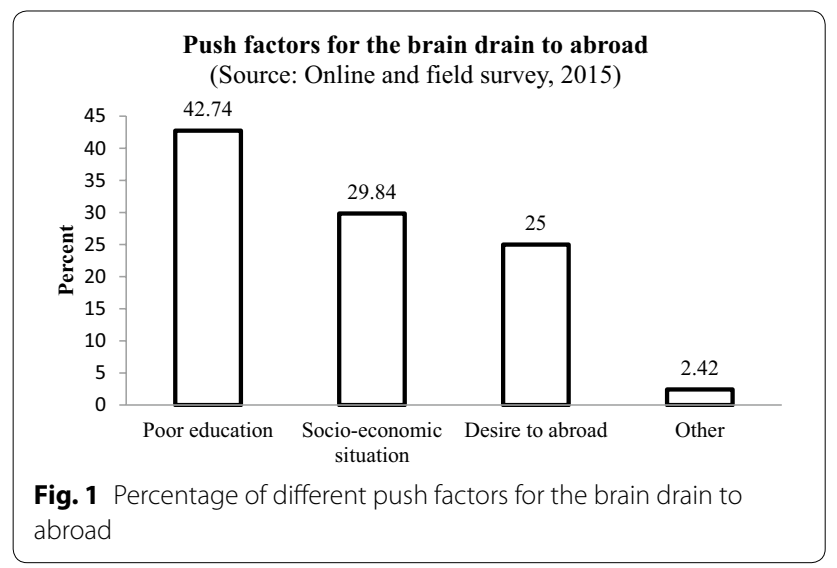

Fig. 1 Percentage of different push factors for the brain drain to abroad

\section{Econometric results: factors affecting brain drain to abroad}

Description of the variables

Table 3 presents description of the variables used in Logit model. The average age $(A G E)$ of the respondents was found to be 25.47 years and the average age of brain drained respondents to abroad was higher (28.24 year) as compared to non-brain drain of the agriculture and veterinary respondents (25.14 year). The age difference between brain drain and non-brain drain respondents was found statistically significant at $1 \%$ level. Similarly, altogether there were about $63 \%$ male respondents in this study (GENDER) which accounts 69 and $62 \%$ male respondents in brain drain and non-brain drain agriculture and veterinary students, respectively. The average household size (HHSIZE) of the respondents was

\section{Pulling factors for the brain drain to abroad (Source: Online and field survey, 2015)}

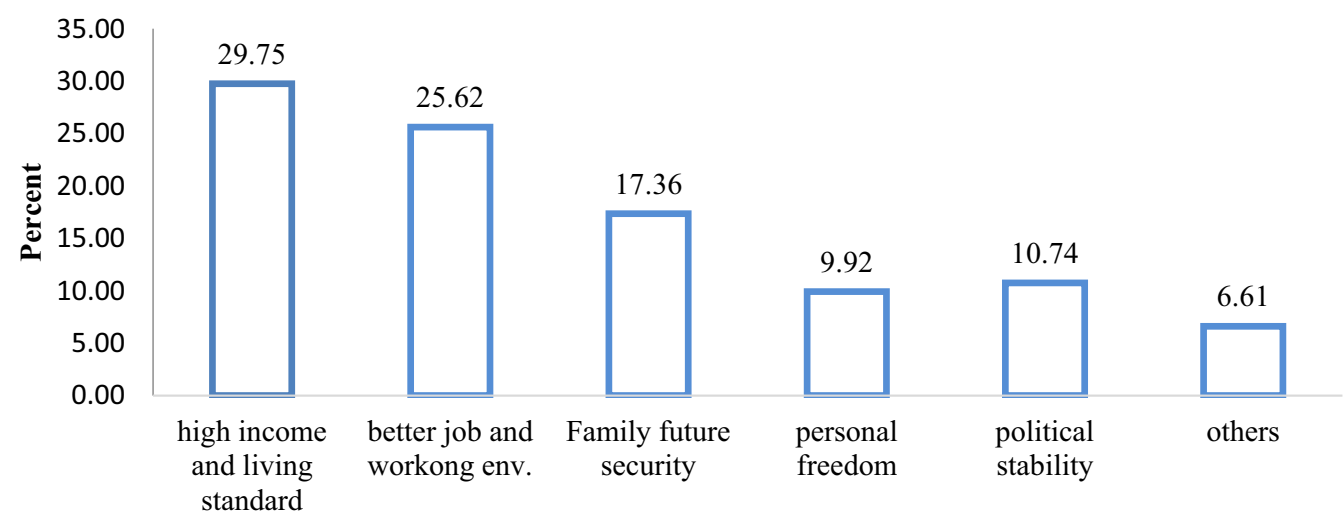

Fig. 2 Percentage of different pull factors for brain drain to abroad

Table 3 Description of the variables used in Logit model

\begin{tabular}{|c|c|c|c|c|c|c|}
\hline Variables & Description & Observation & Overall & $\begin{array}{l}\text { Brain } \\
\text { drain } \\
(n=43)\end{array}$ & $\begin{array}{l}\text { Non-brain } \\
\text { drain } \\
(n=358)\end{array}$ & Mean difference \\
\hline$A G E$ & Age of respondent (year) & 394 & 25.47 & 28.28 & 25.14 & $3.14^{* * *}$ \\
\hline GENDER & Gender of the respondent (male $=1$, otherwise 0 ) & 392 & 0.63 & 0.69 & 0.62 & 0.07 \\
\hline HHSIZE & Total family member in household & 400 & 5.38 & 5.25 & 5.40 & -0.15 \\
\hline MARITAL & Marital status of the respondent (married = 1, otherwise 0 ) & 392 & 0.29 & 0.51 & 0.26 & $0.25^{* * *}$ \\
\hline OCCUPATION & $\begin{array}{l}\text { Major occupation of the household head (agriculture }=1 \text {, } \\
\text { otherwise 0) }\end{array}$ & 401 & 0.31 & 0.30 & 0.32 & -0.02 \\
\hline EDU_MOTHER & Mother's education (literate $=1$, otherwise 0 ) & 401 & 0.85 & 0.86 & 0.84 & 0.02 \\
\hline INCOME_HH & Total annual HH Income (NRs.) (natural log transformation) & 379 & 10.63 & 10.78 & 10.61 & 0.17 \\
\hline MIGRATION_HH & $\begin{array}{l}\text { Family member's migration status (migrated }=1 \text {, otherwise } \\
0 \text { ) }\end{array}$ & 381 & 0.22 & 0.42 & 0.19 & $0.23^{* * *}$ \\
\hline
\end{tabular}

Mean difference is based on $t$ statistics

${ }^{* * *} p \leq 0.01$ 
found 5.38 members. In case of marital status of the respondents (MARITAL), 29\% were married which was found higher among brain drain respondents (51\%) as compared to non-brain drain respondents (26\%) and the difference was statistically significant at $1 \%$ level. About 31\% respondents' household head occupation (OCCUPATION) was found agriculture, whereas 85\% respondents' mothers were found literate in education (EDU_MOTHER). In case of out migration of household member to abroad for better job opportunity (MIGRATION_HH), 22\% were migrated to abroad which was found higher among brain drain respondents $(42 \%)$ as compared to non-brain drain (19\%) and found statistically significant at $1 \%$ level. With respect to total annual household income (INCOME_HH), the differences in household ( $\mathrm{HH})$ income among brain drain and nonbrain drain respondents were statistically nonsignificant.

\section{Determination of brain drain factors using Logit model}

Logit model was used to determine the factors affecting brain drain of agriculture and veterinary graduates. Logit model was used for three different cases. Those who are already migrated to abroad (Brain drain $=1$ ), plan to go abroad after graduation (Yes $=1)$ and already migrated respondents plus willing to go abroad (Yes $=1$ ) were taken as dependent variables in Logit model. The explanatory variables used in these models are described in Table 3.

Case I (Model 1): Already migrated to abroad (Yes=1) as a dependent variable:

The results showed that age of the agriculture graduate $(A G E)$, family members' migration status (MIGRA$\left.T I O N_{-} H H\right)$ were major factors for determining brain drain. For those $\mathrm{HH}$ who had migrated member to abroad, the probability of brain drain increases by about $12 \%$ and was statistically significant at $1 \%$ level. The result revealed that increase in age of the respondents by 1 year, the probability of brain drain increases by about $0.5 \%$ and was found statistically significant at $10 \%$ level.

Case II (Model 2): Plan to go abroad after graduation (Yes $=1)$ as a dependent variable:

In this case, occupation of household head (HHH) and migration status of $\mathrm{HH}$ were the major factor influencing toward brain drain of agriculture and veterinary graduates. With respect to occupation, if the occupation of $\mathrm{HHH}$ was agriculture, then the probability to plan to go abroad decreases by about $15 \%$ and it was found statistically significant at $10 \%$ level. It might be due to the fact that the majority of farmers in Nepal are poor and receive low return from agricultural production. The Visa processing charge and other expenses to go abroad are also high, and they are unable to afford this high charge by the $\mathrm{HH}$ having agriculture as their main occupation. On the other hand, it might be due to farmers' enforcing their educated children to work in Nepal and do believe that could raise their social status in the society. Therefore, the probability to plan abroad by such $\mathrm{HH}$ decreases. Similarly, for those HH who had any of the family member migrated to abroad, the probability of agriculture and veterinary graduates to plan abroad increases by about $15 \%$ and it was found statistically significant at $10 \%$ level. It might be due to ease in abroad processing, mentality to go abroad and some push and pull factors as shown in Figs. 1 and 2.

Case III (Model 3): Already migrated to abroad plus plan to go abroad (Yes $=1$ ) as a dependent variable:

Age of respondent, household income and migration status of the household were found statistically significant variables to determine brain drain of agriculture and veterinary graduates staying at abroad and planning to go abroad. Visualizing the marginal effect of statistically significant explanatory variables, it was found that increase in the age of respondent by 1 year, the probability of brain drain to abroad would increase by about $2 \%$ which was found statistically significant at $10 \%$ level. Similarly, for those $\mathrm{HH}$ who has any family member migrated to abroad, the probability of brain drain to abroad was increased by about $13 \%$ and it was statistically significant at $1 \%$ level. Similarly, increase in total household income by $1 \%$, the probability of brain drain would decrease by about $0.02 \%$ and it was found statistically significant at $10 \%$ level. Whereas other variables such as gender, marital status of the respondent and mother's education influence positively to brain drain but were found statistically nonsignificant, however, agricultural occupation of household head had negative coefficient but it was also statistically nonsignificant (Table 4). The findings revealed that brain drain to abroad among agriculture and veterinary graduates from Nepal are individual characteristic with household features.

\section{Conclusion}

From this study, we concluded that brain drain is becoming serious issue in agriculture and veterinary sector as more than half of the students from this sector intends to go abroad. This situation leads to heavy loss in investment for production of graduates in this sector. Realizing the push and pull factors for brain drain, government should focus on developing plans to retain graduates in the country by creating suitable job opportunities and better facilities. Capable and skilled manpower are the pillars of rapid economic growth and development of the country.

Focusing on agriculture and veterinary graduates, education system should be made strong. Being technical field, well-equipped research laboratories, various 
Table 4 Factors influencing to brain drain and plan after graduation

\begin{tabular}{|c|c|c|c|c|c|c|}
\hline \multirow[t]{2}{*}{ Variables } & \multicolumn{2}{|c|}{ Brain drain (yes $=1$ ) } & \multicolumn{2}{|c|}{$\begin{array}{l}\text { Plan to go abroad after graduation } \\
(\text { yes }=1)\end{array}$} & \multicolumn{2}{|c|}{$\begin{array}{l}\text { Brain drain (already } \\
\text { abroad plus plan to go abroad }=1 \text { ) }\end{array}$} \\
\hline & Coefficient & $\mathrm{dy} / \mathrm{d} x$ & Coefficient & $\mathrm{dy} / \mathrm{d} x$ & Coefficient & $\mathrm{dy} / \mathrm{d} x$ \\
\hline$A G E$ & $0.056^{*}(0.035)$ & $0.005^{*}(0.003)$ & $0.020(0.033)$ & $0.005(0.008)$ & $0.110^{* * *}(0.035)$ & $0.020^{* * *}(0.006)$ \\
\hline GENDER & $0.449(0.397)$ & $0.041(0.036)$ & $0.244(0.287)$ & $0.059(0.067)$ & $0.433(0.278)$ & $0.079(0.050)$ \\
\hline HHSIZE & $-0.046(0.113)$ & $-0.004(0.010)$ & $0.039(0.089)$ & $0.009(0.021)$ & $0.020(0.075)$ & $0.003(0.013)$ \\
\hline MARITAL & $0.661(0.454)$ & $0.061(0.042)$ & $-0.188(0.455)$ & $-0.045(0.109)$ & $0.395(0.365)$ & $0.072(0.066)$ \\
\hline OCCUPATION & $-0.229(0.426)$ & $-0.021(0.039)$ & $-0.605^{*}(0.329)$ & $-0.146^{*}(0.077)$ & $0.131(0.291)$ & $0.024(0.053)$ \\
\hline EDU_MOTHER & $0.145(0.580)$ & $0.013(0.053)$ & $0.088(0.440)$ & $0.021(0.106)$ & $0.032(0.397)$ & $0.006(0.072)$ \\
\hline INCOME_HH & $-0.096(0.070)$ & $-0.008(0.006)$ & $0.019(0.074)$ & $0.004(0.018)$ & $-0.107^{*}(0.055)$ & $-0.019 *(0.009)$ \\
\hline MIGRATION_HH & $1.268^{* * *}(0.367)$ & $0.117^{* * *}(0.033)$ & $0.631^{*}(0.348)$ & $0.152^{*}(0.081)$ & $0.724^{* * *}(0.283)$ & $0.132 * * *(0.050)$ \\
\hline Constant & $-3.319^{* *}(1.328)$ & & $-0.933(1.243)$ & & $-3.358^{* * *}(1.046)$ & \\
\hline No. of observation & 116 & & 251 & & 367 & \\
\hline LR value (8) & $26.53^{* * *}$ & & 8.41 & & $53.16^{* * *}$ & \\
\hline Pseudo- $R^{2}$ & 0.10 & & 0.02 & & 0.11 & \\
\hline
\end{tabular}

Standard errors in parentheses

${ }^{* * *} p \leq 0.01 ;{ }^{* *} p \leq 0.05 ;{ }^{*} p \leq 0.1$

equipments and research plots are very important to conduct higher education and researches smoothly. Along with brain drain, it is also youth drain as most of the migrants are aged between 21 and 30 years of agegroup. As youths of this age are competent, enthusiastic and energetic, they should be provided competitive platform to show their expertise with attractive incentives. Abroad study is better for exchange of knowledge system and technologies but bringing them back is very important to utilize the knowledge gained by them.

Political stability and development in industrial sector should be focused to create employment opportunities. The better environment and good governance might attract the migrated individuals. The study suggests that brain drain is individual features in least developed country like Nepal, so government should formulate better policy to control brain drain considering all consequences that can hamper economic growth of the country.

\section{Abbreviations}

\%: percent; US\$: United States Dollar; AFU: Agriculture and Forestry University; EU: European Union; GDP: Gross Domestic Product; $\mathrm{HH}$ : household; $\mathrm{HHH}$ : household head; IAAS: Institute of Agriculture and Animal Science; I/NGOs: International/Non-governmental Organizations; LDCs: least developed countries; Ph.D.: Doctor of Philosophy; SPSS: Statistical Packages for Social Sciences; TU:Tribhuvan University; USA: United States of America.

\section{Authors' contributions}

RRK is the principal researcher of this study. He designed the overall study, guided to all students during questionnaire design, data collection, data extract, analysis and prepared the initial draft and final manuscript. MS is the co-researcher of this study who helped main author in every steps of this study. He and his colleagues prepared online questionnaire, collected data, data entry and made necessary analysis. He collected necessary literature for this study, support to prepare draft manuscript, finalized the final manuscript and drafted the manuscript to journal. Both authors read and approved the final manuscript.

\section{Author details}

${ }^{1}$ Department of Agricultural Economics and Agribusiness Management Faculty of Agriculture, Agriculture and Forestry University (AFU), Rampur, Chitwan, Nepal. ${ }^{2}$ Department of Agriculture, Ministry of Agriculture and Livestock Development, Hariharbhawan, Lalitpur, Nepal.

\section{Acknowledgements}

Authors are grateful to M.Sc.Ag. (Agricultural Economics) students of second semester (2014-2016 batch of AFU) (especially Sagar Bista, Ramjiwan

Thakur, Mahima Bajracharya, Prakash Pant and all others) at Department of Agricultural Economics and Agribusiness Management for their contribution in questionnaire design, data collection and basic analysis. Authors are also deeply indebted to the agriculture graduates and students those who were studying agriculture and veterinary sciences in Nepal.

\section{Competing interests}

We would like to declare that there are no competing interests among the authors.

\section{Availability of data and materials}

The datasets used and analyzed during the current study are available from the corresponding and main author on reasonable request.

\section{Consent for publication}

A verbal consent for publication has been received from the participants in this study under the condition of anonymity, which was strictly maintained in this paper.

\section{Data and funding}

Data were collected by M.Sc.Ag. (Agricultural Economics) postgraduate students in Econometrics course in 2015 under the supervision and quidance of main author. The online survey questionnaire was developed and applied to collect data and analysis was done using SPSS and Stata software. No external funding was available in this study.

\section{Ethics approval and consent to participate}

Not applicable. 


\section{Publisher's Note}

Springer Nature remains neutral with regard to jurisdictional claims in published maps and institutional affiliations.

Received: 4 January 2018 Accepted: 21 August 2018

Published online: 30 August 2018

\section{References}

1. Asgari $\mathrm{H}$. An investigation of brain drain from Iran to OECD countries based on gravity model. Iran Econ Rev. 2011;15(29):89-99.

2. Economic Survey 2015. Economic Survey, 2015. Ministry of Finance, Government of Nepal. http://www.mof.gov.np/en/archive-documents/ economic-survey-21.html.

3. Bhattarai P. Migration of Nepalese youth for foreign employment: problems and prospects: a review of government policies and programs. October Central Bureau of Statistics/National Planning Commission. 1997. "Report on Nepal Labor Force Survey, 1996." 2005

4. Chaudhary PK, Pasa RB. Agriculture education for rural development in Nepal. J Train Dev. 2015;1(1):38-45.

5. Pokhrel D. Brain drain of agriculture scientists (Nepali). Karobar Daily. March 28th, 2013. http://tinyurl.com/nly7u95. 2013.

6. IRIN. Analysis: the trouble with Nepal's agriculture. Published on Jan 23, 2013. http://www.irinnews.org/report/97321/analysis-trouble-nepal \%E2\%80\%99s-agriculture. 2013.
7. Musumba M, Jin YH, Mjelde JW. Factors influencing career location preferences of international graduate students in the United States. Educ Econ. 2011;19(5):501-17.

8. Chetsanga CJ, Muchenje TB. An analysis of the cause and effect of the brain drain in Zimbabwe. Scientific and Industrial Research and Development Centre, Harare. 2003.

9. Tansel A, Gungor ND. 'Brain drain' from Turkey: survey evidence of student non-return. Career Dev Int. 2003;8(2):52-69.

10. Iravani MR. Brain drain problem: a review. Int J Bus Soc Sci. 2011;2(15):284-9.

11. Commander S, Kangasniemi M, Alan Winters $L$. The brain drain: a review of theory and facts. Bruss Econ Rev. 2004;47(1):29-44.

12. Gouda P, Kitt K, Evans DS, Goggin D, Last J, Hennessy M, Arnett R, O'Flynn $\mathrm{S}$, Dunne F, O'Donovan D. Ireland's medical brain drain: migration intentions of Irish medical students. 2015;13:11. https://doi.org/10.1186/s1296 0-015-0003-9

13. Oyelere RU. Brain drain, waste or gain? What we know about the Kenyan Case. J Glob Intiatives. 2007;2(2):113-29.

14. Johnson N. Analysis and assessment of the brain drain phenomenon and its effects on Caribbean countries. Fla Atl Comp Stud J. 2008;2009(11):1.

15. Riano $Y$. The invisibility of family in studies of skilled migration and brain drain. Diversities. 2012;14(1):25-44.
Ready to submit your research? Choose BMC and benefit from:

- fast, convenient online submission

- thorough peer review by experienced researchers in your field

- rapid publication on acceptance

- support for research data, including large and complex data types

- gold Open Access which fosters wider collaboration and increased citations

- maximum visibility for your research: over $100 \mathrm{M}$ website views per year

At BMC, research is always in progress.

Learn more biomedcentral.com/submissions 